\title{
Certain immunologic substances in the serum of patients with myocardial infarction and other cardiovascular diseases
}

\author{
Vernon N. Dodson, M.D.* \\ Park W. Willis, III, M.D.** \\ Lucas deVries, M.S.*** \\ Mary E. Clifford, M.D. ${ }^{* * * *}$ \\ Ann Arbor, Mich.
}

\begin{abstract}
$\mathrm{A}^{\mathrm{n}}$ nti-heart antibodies have been detected by different immunologic methods in the serum of patients with various heart diseases, especially that of rheumatic origin. ${ }^{1-5}$ The prevalence of these serum antibodies in patients with nonrheumatic heart disease has been relatively low. ${ }^{5-8}$ Thus, the adjunctive use of immunologic methods for the clinical detection of heart disease appeared to be of limited value unless the sensitivity and yield of significant positives could be increased. This paper reports further studies on anti-heart serum factors which increase the diagnostic potential of such blood tests in patients with heart disease, especially myocardial infarction.
\end{abstract}

\section{Methods and materials}

Samples of serum were taken from patients with myocardial infarction. Serum from normal people and hospital patients with various diseases was also studied.
In this study, a patient was considered to have a myocardial infarction if the electrocardiogram (ECG) showed typical changes of transmural infarction or if atypical changes were accompanied by an elevated serum glutamic oxaloacetic transaminase activity (SGOT). The antigens used in this study were prepared from human tissues which were histologically normal, obtained at postmortem within 6 hours of death from individuals with type O blood, whose clinical course and postmortem examination revealed no evidence of cancer or infection. A modification of the Boyden tanned red blood cell hemagglutination tests was employed to detect anti-organ antibodies in the serum. ${ }^{9}$ Trpet $O$ human erythrocytes were coated with a 1:1000 gram-volume concentration of tissue antigen extract prepared in the following way: One gram of freshly washed tissue was homogenized in $10 \mathrm{ml}$. of phosphate-buffered normal saline, $\mathrm{pH}$ 6.4. for

\footnotetext{
From the Department of Internal Medicine, School of Medicine, Department of Industrial Health, School of P'ublic Health, and the Institute of Industrial Health, University of Michigan, Ann Arbor, Mich.

This investigation was supported in part by a research grant from the Michigan Heart Association.

Received for publication April 12, 1966.

*Associate Professor of Internal Medicine and of Industrial Health, and Research Associate, Institute of Industrial Ilealth. Address: School of Public Health, University of Michigan, Ann Arbor, Mich., 48104.

* Professor of Internal Medicine.

*** Graduate Student, Department of Epidemiology, School of Hublic Health.

wok* Assistant Professor, Internal Medicine
} 
2 minutes at $4^{\circ} \mathrm{C}$, using a Virtis homogenizer. The homogenate was allowed to extract for 15 minutes at $4^{\circ} \mathrm{C}$. and then was centrifuged at 1,500 r.p.m. for 10 minutes. The supernatant was diluted 1:100 with the buffered saline. All extracts were prepared fresh and used within 90 minutes. All runs contained the following controls: a positive serum of known titer, a negative serum, and a typical checkerboard of cross reactions between all reactants. If the test serum did not hemagglutinate heart-extract-sensitized tanned erythrocytes, then a test for the presence of inhibitors was performed by adding a constant volume of anti-heart positive serum to each tube of the negative test serum and the negative control serum series so that the tubes of the negative control series became positive. The tubes were shaken, the cells resuspended, and the test was read after 2 hours. If inhibitors were present, the tubes containing higher concentrations of test serum suppressed hemagglutination, whereas those containing lower concentrations did not. The titer of the inhibitor was taken as the dilution of the last tube in which hemagglutination was suppressed. Some of the sera which gave negative results on direct hemagglutination were incubated with positive anti-heart antiserum or with heart-extract-sensitized tanned red blood cells prior to repeating the test, in order to ascertain whether the site of action of the inhibition was with antibodies in the antiserum or with antigen on the erythrocytes or at both of these locations. Cross reactions with other organ extracts were studied with hemagglutination and hemagglutination-inhibition methods.

\section{Results}

Table I presents the results of direct and inhilition hemagglutination tests performed on the serum of normal people and on that of patients with nyocardial infarction. The infarctions had occurred 9 days to 1.5 years earlier. The difference in the prevalence of positive hemagglutination tests between the group with myocardial infarction and the normal group is sirnificant for both direct $(\mathrm{p}<0.05)$ and inhibition $(0.025>\mathrm{p}>0.01)$ testing.

Table II presents the data on serum hemagglutination tests in patients with various diseases. Direct hemagglutination occurred in cases of heart disease. Positive inhibition reactions occurred in patients with diseases which usually involve blood vessels, e.g., lupus erythematosus, syphilitic aortitis, and pulmonary embolism.

Table III presents the results of tests for the presence of anti-heart hemagglutination inhibitors in sera which were negative for anti-heart antibodies by direct hemagglutination. When the test sera were preincubated with the antigen-coated cells, the results were identical to those obtained with the initial inhibition test. Inhibition occurred with the serum from one patient in the myocardial infarction group (No. 5), and with that from the three persons in the normal group (Nos. 8,9 , and 10), regardless of whether preincubation was with antigen-coated cells or anti-heart antiserum. All four had titers of $1: 128$ or 1:256. Serum from Patients Nos. 2, 4, and 7 inhibited only after incubation with anti-heart antiserum.

Table IV lists the hemagglutination test results with the intervals since the oldest and most recent infarctions.

Table I. Results of serum anti-human heart hemagglutination tests in normal people and patients with myocardial infarction*

\begin{tabular}{l|c|c|c|c|c|c}
\hline \multirow{2}{*}{ Patient groups } & \multicolumn{2}{|c|}{ Direct hemagglutination } & \multicolumn{2}{c}{ Inhibition hemagglutination } \\
& Positive & Negative & Total & Positive & Negative & Total \\
& 8 & 15 & 23 & 7 & 6 & 13 \\
\hline $\begin{array}{l}\text { Myocardial infarction } \\
\text { Normal }\end{array}$ & 3 & 47 & 50 & 3 & 20 & 23 \\
\hline
\end{tabular}


Table II. Results of serum anti-heart hemagglutination tests in patients with various diseases*

\begin{tabular}{|c|c|c|c|c|c|c|}
\hline \multirow{2}{*}{ Disease } & \multicolumn{3}{|c|}{ Direct hemagglutination } & \multicolumn{3}{|c|}{ Inhibition hemagglutination } \\
\hline & Positive & Negative & Total & Positive & Negative & Total \\
\hline Cardiomyopathy & 2 & 3 & 5 & 1 & 2 & 3 \\
\hline $\begin{array}{l}\text { Miscellaneous } \\
\text { Rheumatoid arthritis } \\
\text { Rheumatic heart disease } \\
\text { Lupus erythematosus (SI.E) } \\
\text { Syphilitic aortitis } \\
\text { Pulmonary embolism } \\
\text { Pleurisy } \\
\text { Electrical shock } \\
\text { Cancer of pancreas } \\
\text { Osteoarthritis }\end{array}$ & $\begin{array}{l}1 \\
4 \\
0 \\
0 \\
0 \\
0 \\
0 \\
0 \\
0\end{array}$ & $\begin{array}{l}0 \\
1 \\
1 \\
1 \\
1 \\
1 \\
1 \\
1 \\
1\end{array}$ & $\begin{array}{l}1 \\
5 \\
1 \\
1 \\
1 \\
1 \\
1 \\
1 \\
1\end{array}$ & $\begin{array}{l}0 \\
1 \\
1 \\
1 \\
1 \\
0 \\
0 \\
0\end{array}$ & $\begin{array}{l}1 \\
0 \\
0 \\
0 \\
0 \\
1 \\
1 \\
1\end{array}$ & $\begin{array}{l}1 \\
1 \\
1 \\
1 \\
1 \\
1 \\
1 \\
1\end{array}$ \\
\hline
\end{tabular}

*Numbers indicate the number of people in each category.

Table III. Results of anti-heart hemagglutination inhibition tests

\begin{tabular}{|c|c|c|c|c|}
\hline \multirow{2}{*}{$\begin{array}{l}\text { Patient } \\
\text { number }\end{array}$} & \multirow{2}{*}{$\begin{array}{c}\text { Direct } \\
\text { hemagglutination }\end{array}$} & \multirow{2}{*}{$\begin{array}{c}\text { Initial inhibition } \\
\text { test }\end{array}$} & \multicolumn{2}{|c|}{ Pre-incubation with } \\
\hline & & & $\begin{array}{l}\text { Heart antigen- } \\
\text { coated red } \\
\text { blood cells }\end{array}$ & $\begin{array}{l}\text { Anti-heart } \\
\text { antiserum }\end{array}$ \\
\hline \multicolumn{5}{|l|}{$\begin{array}{l}\text { Myocardial } \\
\text { infarction }\end{array}$} \\
\hline 1. & - & + & + & - \\
\hline 3. & - & + & + & - \\
\hline 5. & - & + & + & + \\
\hline 6. & - & + & + & - \\
\hline 2. & - & - & - & + \\
\hline 4. & - & - & - & + \\
\hline 7. & - & - & - & + \\
\hline \multicolumn{5}{|l|}{ Normal } \\
\hline 8. & - & + & + & + \\
\hline 9. & - & + & + & + \\
\hline 10. & - & + & + & + \\
\hline
\end{tabular}

\section{Discussion}

The sera of 29 per cent of the patients with myocardial infarction gave positive anti-heart hemagglutination tests, as compared to 6 per cent in the normal group $(\mathrm{p}<0.005)$. This low frequency of positive tests in normal individuals has been reported. ${ }^{2,5,10,11}$ The prevalence of positive tests in the group with myocardial infarction compares favorably with the experi- ence of others employing similar nuethods $^{5,6,11}$ and precipitin procedures ${ }^{12}$ but is less than that observed with immunofluorescent techniques. ${ }^{13}$ Four of 5 patients with inactive rheumatic heart disease had positive anti-heart hemagglutination tests. This is similar to the frequency (92 per cent) reported by Zablocki. ${ }^{3}$ Hess and Fink ${ }^{6}$ found 63 per cent positive results in patients with active rheumatic 
Table IV. Intervals between anti-heart hemagglutination tests and myocardial infarction

\begin{tabular}{|c|c|c|c|}
\hline \multicolumn{2}{|c|}{ Interval since myocardial infarction } & \multirow{2}{*}{$\begin{array}{l}\text { Direct hemagglutination } \\
\text { (reciprocal of titer) }\end{array}$} & \multirow{2}{*}{$\begin{array}{c}\text { Inhibition hemagglutination } \\
\text { (reciprocal of titer) }\end{array}$} \\
\hline First & Last or only & & \\
\hline \multirow[t]{2}{*}{$10 \mathrm{yr}}$. & ? & 256 & \\
\hline & 14 days & 32 & \\
\hline \multirow[t]{4}{*}{$15 \mathrm{yr}$. } & $22 \mathrm{mo}$ & 64 & \\
\hline & 18 days & 4 & \\
\hline & 9 days & 256 & \\
\hline & $6 \mathrm{mo}$ & 4 & \\
\hline $4 \mathrm{yr}$ & 21 days & 128 & \\
\hline $3 \mathrm{yr}$. & $?$ & 128 & \\
\hline $8 \mathrm{mo}$. & 6 days & Negative & 128 \\
\hline ? & $8 \mathrm{yr}$ & Negative & 128 \\
\hline$?$ & 7 days & Negative & 1,028 \\
\hline \multirow[t]{5}{*}{$10 \mathrm{yr}}$. & 47 days & Negative & 0 \\
\hline & 11 days & Negative & 0 \\
\hline & $2 \mathrm{mo}$ & Negative & 128 \\
\hline & 45 days & Negative & 0 \\
\hline & $\bar{j}$ & Negative & 0 \\
\hline
\end{tabular}

$?=$ Exact date of infaretion not known.

heart disease, but only 16 per cent in patients in whom the disease was in the inactive stage. Occasional reports of tests of the serum of individuals with "cardiomyopathy" have been included in papers on anti-heart serum factors. ${ }^{1}$ Two of 5 such patients in this study had anti-heart antibodies.

These findings indicate a firm relationship between anti-heart serum hemagglutinins and structural heart disease, with the former being more likely an effect than a cause of the heart disease, except, perhaps, in the case of acute rheumatic fever. ${ }^{7,14,16}$ There appears to be no clear relationship to a single pathologic change in the heart, since anti-heart hemagglutination reactions occurred in patients whose hearts were involved by acute or chronic inflammatory, degenerative, or necrotic processes, a situation also reported by others. ${ }^{2,14,17}$ It would seen that these patients are responding to a number of heart antigens by forming immunoglobulins that range from relatively nonspecific to cross reacting or highly specific. ${ }^{11,15,18-21}$ Serum from normal individuals and from patients with vascular or other cardiac diseases did not often give the positive anti-heart hemagglutination test results commonly encountered with serum from patients with myocardial infarction, rheumatic heart disease, or cardiomyopathy. There was no association between the presence or titer of anti-heart hemagglutinins and the number of infarctions or the interval since infarction. In rheumatic heart disease, cross-reacting antistreptococcal wall antibodies, as well as anti-heart factors, could be responsible for the positive tests observed. Anti-heart serum factors have been reported in lupus erythematosus and syphilis, ${ }^{3,11,12}$ but were not detected in this study. The serum in one case of inactive rheumatoid arthritis produced hemagglutination at a titer of 1:16.

Anti-heart hemagglutination inhibitors were more frequently encountered in the serum of patients with myocardial infarction than in that of normal subjects (Table I), but were observed in the serum of patients with cardiomyopathy, lupus erythematosus, syphilitic aortitis, pulmonary embolism, and pleurisy. Except for the case of pleurisy, they were not found in the absence of cardiac or vascular disease (Table II).

Three types of anti-heart hemaggluti- 
nation inhibition are observed: at the antigen site, at the antiserum site, or at both sites. Except for the serum of one patient with myocardial infarction, dual inhibition occurred only in the serum from 3 normal subjects. Anti-heart inhibitors are relatively uncommon in normal individuals, in contrast to patients with myocardial infarction. They are also observed in persons with other diseases in which there is cardiac or vascular involvement (cardiomyopathy, lupus erythematosus, syphilitic aortitis, and pulmonary embolism). Inhibition was not present in the one case of inactive rheumatic heart disease studied.

It seems, therefore, that chronic inflammatory mechanisms involving the cardiovascular system are frequently associated with solitary anti-heart hemagglutination inhibitors acting at either the antigen or antiserum site. Sera exhibiting dual inhibition are less specific and were found in normal subjects and in one patient with myocardial infarction. Inhibitors in serum were observed as early as 6 days and as late as 2 months after myocardial infarction (Table $1 \mathrm{~V}$ ). Titers ranged from 1:128 to $1: 1028$ and were present in persons with one infarction as well as in those with several infarctions. There were no apparent correlations between the titers of inhibitors, the time since infarction, or the number of infarctions.

The immunologic significance of these findings is difficult to assess. The inhibition observed against the heart antigens could le explained by the presence of incomplete anti-heart antibodies or cross-reacting immunoglobulins, but is more likely due to anti-heart immunoglobulins of the $G_{S}$ or 7 s type. ${ }^{22-24}$ Inhibition occurring at the antiserum site could be the result of circulating heart antigens, other tissue antigens possessing similar determinants, ${ }^{2-2}$ or antiganmaglobulins (e.g., serun normal agglutinators, rheumatoid agglutinators, "Milgrom factors," etc. ${ }^{25}$ ). The nonspecific dual inhibition could be explained by the presence of several of the latter factors, especially those immunoglobulins acting against antigen-antibody complexes, gammaglobulin aggregates, or proteins with semi-available determinants. Other inves. tigators have presented evidence to sug- gest that damaged tissue itself releases nonspecific immunoglobulins which persist for wecks. ${ }^{26,27}$

Although the reason for the presence of the anti-heart inhibitors is not apparent, they are found in the serum of patients with heart disease and may prove to have diagnostic usefulness.

\section{Summary}

Serum anti-heart hemagglutinins occurred in 29 per cent of patients with myocardial infarction, as compared to 6 per cent of normal control subjects, had a high prevalence in patients with rheumatic heart disease, occurred in 2 of 5 with a cardionyopathy, and had a very low frequency in individuals who had noncardiac diseases with or without a vascular component.

Serum inhibitors of anti-heart hemagglutinations were found in one half of the patients with myocardial infarction and in those having diseases with vascular involvement, e.g., lupus erythematosus, pulmonary embolism, and syphilitic aortitis. The inhibitors found associated with cardiovascular diseases inhibit at either the antigen or antiserum site during the hemagglutination test, whereas the normal sera which display inhibition do so at both sites, suggesting a lack of anti-heart specificity. From these data it appears that, with the sequential use of both the anti-heart hemagglutination technique and the inhibition test, positive results can be obtained in over one half of the patients with myocardial infarction.

As diagnostic adjuncts, these tests still offer only limited assistance in the clinical detection of cardiovascular diseases. A positive anti-heart hemagglutination inhilition test alone appears to be related to less specific vascular damage.

\section{REFERENCES}

1. Gery, I., Davies, A. M., and Ehrenfeld, E. N.: Heart specific autoantibodics, Lancet 1:471, 1960.

2. Davies, A. M., and Gery, I.: The role of autoantibodies in heart disease, AM. HEakT J. 60:669, 1960.

3. Zablocki, B., Szydlowski, S., Kotelko, K., Szykier, L., Kandel, S., and Odlanicki-Poczobut, A.: Search for antibodies to heart antigens in the sera of patients with rheumatic fever 
and rheumatoid arthritis, Bull. Acad. Pol. Sc. 12:251, 1964.

4. Wagner, V., Zavazal, V., Kasalova, D., Maly, V., Mecl, A., and Prokop, J.: Immunology of toxemias of pregnancy. I. Findings of organspecific antibodies, Experientia 15:24, 1959.

5. Ehrenfeld, E. N., Gery, 1., and Davies, A. M.: Specific antibodies in heart disease, Lancet $1: 1138,1961$.

6. Hess, E. V., and Fink, C. W.: Heart muscle antibodies in rheumatic fever and other diseases, J. Clin. Invest. 43:886, 1964.

7. Yamada, S.: Immunofluorescent studies on antimyocardial antibodies in rheumatic fever and other diseases, J. Jap. Rheum. Assn. 5:195, 1964.

8. Kaplan, M. H.: The concept of autoantibodies in rheumatic fever and in the post-commissurotomy state, Ann. New York Acad. Sc. 86:974, 1960.

9. Boyden, S. J.: The adsorption of proteins on erythrocytes treated with tannic acid and subsequent hemagglutination by antiprotein sera, J. Exper. Med. 93:107, 1951.

10. Robinson, J, and Brigden, W.: Immunologic studies in the postcardiotomy syndrome, Brit. M. J. 2:706, 1963.

11. Djanian, A. Y., Beutner, E. H., and Witebsky, E.: Tanned-cell hemagglutination test for detection of antibodies in sera of patients with myasthenia gravis, J. Lab. \& Clin. Med. 63:60, 1964.

12. Fatenkov, V. N.: Precipitin reaction with myocardial antigens in myocardial infarction and other diseases, (Russian) Terap. Arkh. 33:11, 1961.

13. Van der Geld, H.: Anti-heart antibodies in the postpericardiotomy and the postmyocardialinfarction syndromes, Lancet, 2:617, 1964.

14. Ziffer, A. M., and Klotz, S. D.: Post myocardial infarction syndrome, Ann. Allergy $21: 698,1963$.

15. Kaplan, M. II., and Meyeserian, M.: $\Delta \mathrm{n}$ inmunological cross-reaction between Group A streptococcal cells and human heart tissue, Lancet $1: 706,1962$.

16. Kaplan, M. H., Bolande, R., Rakita, L., and
Blair, J.: Presence of bound immunoglobulins and complement in the myocardium in acute rheumatic fever, New England J. Med. 271:637, 1964.

17. Davies, A. M., Laufer, A., and Gery, I.: Organ specificity of the heart. III. Circulating antibodies and inmunopathological lesions in experimental animals, Arch. Path. 78:369, 1964.

18. Kaplan, M. H., Meyeserian, M., and Kushner, I.: Immunologic studies of heart tissue. IV. Serologic reactions with human heart tissue as revealed by immunofluorescent methods: Isoimmune, Wassermann, and autoimmune reactions, J. Exper. Med. 113:17, 1961.

19. Szent-Györgyi, A. G., and Holtzer, H.: Fixation of muscle proteins with antibodies, Biochim. Biophys. Acta 41:14, 1960.

20. Kesztyüs, L., Nikedemusz, S., and Szilagyi, $T$.: Antigenic activity of myosin and actin, Nature 163:136, 1949.

21. Gery, I., Davies, A. M., and Lazarov, E. Immunity and immuno-tolerance to bovine heart antigens in the rat. Heterogeniety of the serologic response, Immunology 7:182, 1964.

22. Kabat, E. A., and Mayer, M. M.: Experimental immunochemistry, ed. 2, Springfield, Jll., 1961, Charles C Thomas, pp. 241-267.

23. Rozental, K. M., and Romanov, A. F.: Incidence of autoantibodies in the blood of children with theumatic fever, (Russian) Vop. Revm. 4:3-8, 1964.

24. Neff, B. J., Ackermann, W. W., Epstein, F. H., and Francis, T., Jr.: Inhibition of vaccinial hemagglutinins by sera of patients with coronary heart disease and other chronic illnesses, Circulation Res. 10:836, 1962.

25. Kunkel, H. Ct.: Advances in immunology, Vol. IV, New York, 1964, Academic Press, pp. 351-396.

26. Dodson, V. N., Friberg, R., and Ketchum, D.: Chemical, histologic and immunologic responses in rats to $\mathrm{CCl}_{4}$ by different routes of administration, Proc. Soc. Exper. Biol. \& Med. 120:355, 1965

27. Weir, D. M.: Immunological reactions after tissue damage, Lancet $1: 749,1964$. 